\title{
Eskers and bedrock gorges (tunnel valleys) in the Pakasaivo area, western Finnish Lapland
}

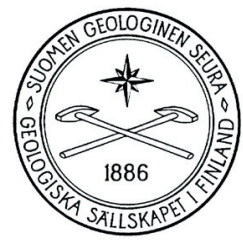

\author{
Peter Johansson \\ Geological Survey of Finland, P.O. Box 77, FIN 96101 Rovaniemi, Finland
}

\begin{abstract}
Studies of the deglaciation of the last Scandinavian Ice Sheet, including the behavior of the ice sheet and meltwater activity, were conducted in the vicinity of the Pakasaivo canyon lake, located in western Finnish Lapland. Pakasaivo itself, a circular basin up to $100 \mathrm{~m}$ deep, was formed in the broken bedrock by glacial erosion and meltwater streams. It was originally related to a former subglacial meltwater system, including the deep Keinokursu gorge. Both this gorge and the Pakasaivo canyon lake were formed subglacially during an early stage of deglaciation. It was characterized by intense meltwater erosion, which in Pakasaivo also seems to have generated a strong whirl. Steep-crested esker ridges were subsequently deposited; subaerial meltwater activity then followed. Finally the meltwater was discharged from the ice-dammed lake north of the area and passed through the Pakasaivo canyon to the ice-free areas. This caused additional intense erosion of the canyon floor and walls, and the deep circular basin is highly similar to a plunge pool formed at the base of a cataract.
\end{abstract}

Key words: glacial geology, deglaciation, subglacial environment, eskers, meltwater channels, canyons, lakes, erosion, Pakasaivo, Lapland Province, Finland

\section{Introduction}

The deglaciation of the Late Weichselian Scandinavian Ice Sheet in northernmost Finland took place mainly in a supra-aquatic environment accompanied by abundant meltwater streams. In northern Scandinavia, Tanner (1915) carried out the first extensive study of subglacial meltwater systems; he provided an overview of both the palaeohydrography of the area and the recession of the ice margin. Mikkola (1932) and Virkkala (1955), among others, continued the study of eskers and related erosional landforms created by meltwater in Finnish Lapland. They concluded that the meltwater systems responsible for long esker sequences were subglacial. When crossing mountain ranges serving as water divides, the subglacial meltwater systems eroded gorges and channels in the overburden,

\footnotetext{
* e-mail: peter.johansson@gsf.fi
}

frequently into the bedrock. In Scandinavia, the British Isles, the USA, and Canada, the majority of esker sequences and related erosional landforms were similarly interpreted as having been formed subglacially (Mannerfelt, 1945; Sissons, 1961; Holtedahl, 1967; Lundqvist, 1969 and 1979, Sugden \& John 1976; Clark \& Walder, 1994; Brennand, 1994 and 2000). In their studies conducted in northern Finland, Penttilä (1963), Kujansuu (1967) and Johansson (1995) applied subglacial paleohydrography to the study of deglaciation, combining it with information on the development of marginal and extramarginal meltwater effects.

The purpose of this study was to analyse the conditions in which the Pakasaivo canyon and the surrounding glaciofluvial erosional and depositional landforms were formed and to determine their relation to the region's meltwater flow and deglaciation. The Pakasaivo area is located in the western part of northern Finland, 


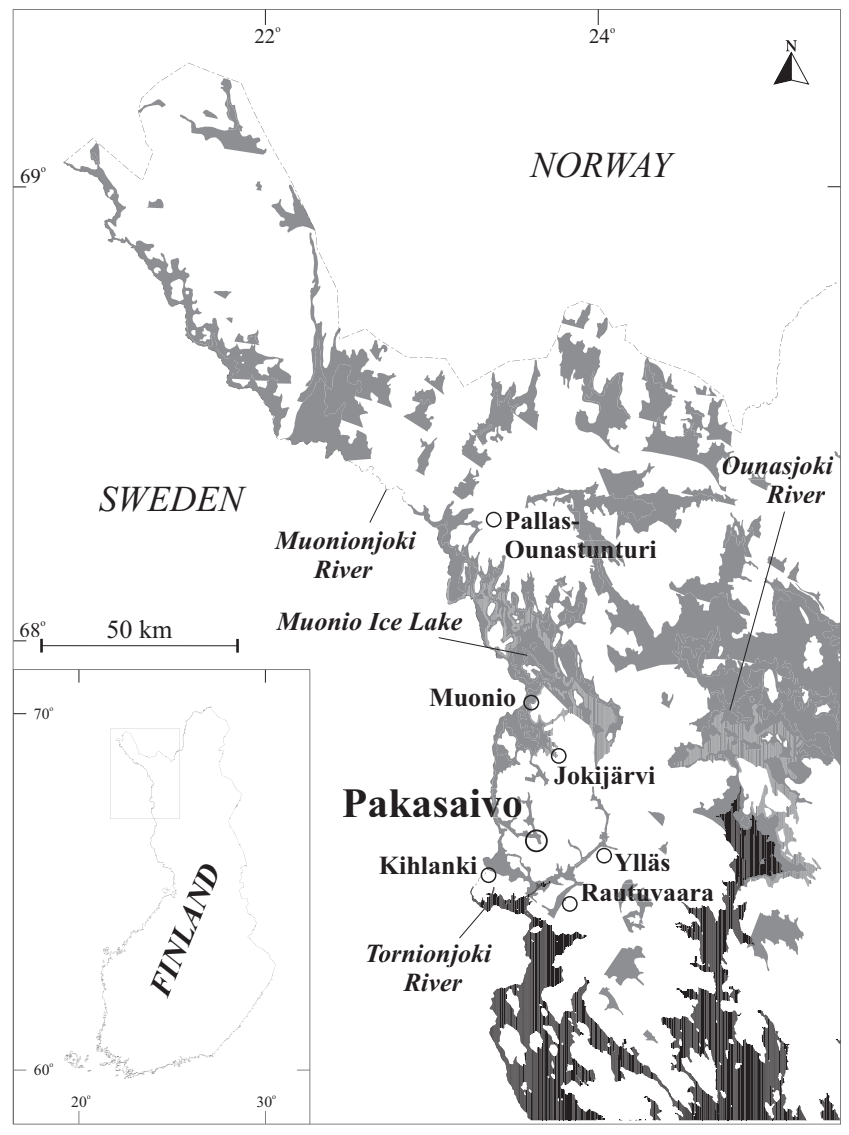

Fig. I. Location of the study area. The areas depicted in gray were once covered by ice-dammed lakes, and the area depicted in black used to be covered by the Baltic Sea. about $120 \mathrm{~km}$ north of the Arctic Circle, at $67^{\circ} 37^{\prime} 00^{\prime \prime} \mathrm{N}$ and $23^{\circ} 47^{\prime} 45^{\prime \prime} \mathrm{E}$ (Fig. 1). It is an uninhabited wilderness region between the western Lapland mountain region and Muonionjoki-Tornionjoki, the river on the border between Finland and Sweden. Pakasaivo itself is a steep-sided canyon with a clear-watered lake at the bottom. It is a protected geologic site that has become popular over the last few years, a result of the region's growing tourist industry and improved roads.

\section{Regional description}

The region around Pakasaivo is underlain by Precambrian bedrock of the Fennoscandian Shield. Acidic plutonic rocks, such as granite and monzonite, are characterized by cubic joint sets (Lehtonen, 1981). The topography is formed by undulating hilly land with glacigenic relief and relative altitude variations of 100 $200 \mathrm{~m}$. During the glaciations the continental ice sheet evened out the landforms. It smoothed and rounded the mountains, depressions and valleys, many of which are expressions of faults and fracture zones of the bedrock.

Multiple glacial advances and retreats in the region have been described from the Rautuvaara mine region $15 \mathrm{~km}$ south of Pakasaivo (Hirvas, 1991). The Early Weichselian till bed and tillcovered eskers around the Rautuvaara region provide evidence of an ice flow from NW to SE. Ice-flow indicators suggest the ice divide was situated south of the study area at the end of the Late Weichselian, and the direction of ice flow was from south to north (Hirvas, 1991). The ice margin receded towards the SW, and the Pakasaivo region was deglaciated less than 10000 


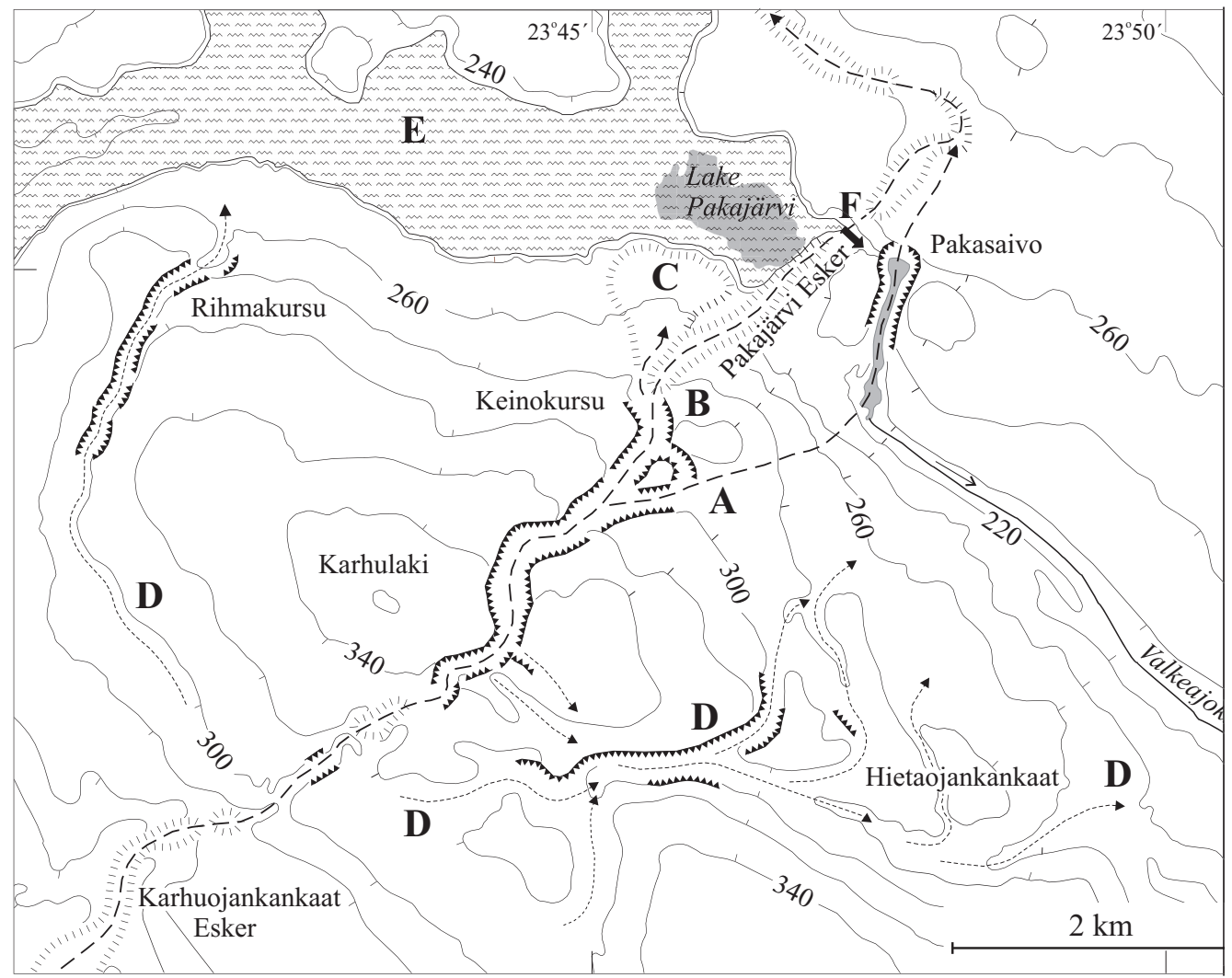

Fig. 2. Subglacial, subaerial, and marginal meltwater systems in the Pakasaivo area. a) Route of a subglacial meltwater stream during its early stage. b) Route of a subglacial meltwater stream during its late stage. c) Subaerial meltwater stream and a kame deposited at its mouth. d) Marginal channel. e) Area covered by the Muonio Ice Lake. f) Spillway of the ice lake leading to Pakasaivo.

years ago (Saarnisto, 2000). During deglaciation, extensive ice-dammed lakes existed north of the study area, and water from them flowed along the ice margin towards the SE, into icefree areas (Fig. 1). After deglaciation of the Muonio River valley, the Ancylus Lake, an ancient phase of the Baltic, extended up the river valley to a point about $20 \mathrm{~km}$ south of the present study area (Fig. 1).

\section{The morphology of the Pakasaivo canyon lake}

Western Finnish Lapland has a number of clearwatered lakes and ponds named "saivo", being round or oval in shape and 50-200 $\mathrm{m}$ in diameter. The saivo lakes are exceptionally deep, and some of them are characterized by steep slopes and cliffs that resemble deep, water-filled canyons. Other saivo lakes are groundwater-fed hollows or kettles between esker ridges. The saivo lakes are not a genetically classified type of lake, but their round shape and great depth make them representative of the region.

Pakasaivo lake, which is 1.1 kilometers long, is located within a N-S trending fracture zone of the monzonite bedrock (Fig. 2). Its southern end has gently sloping, stony till shores. In the northerly direction, the enclosing basin rises and becomes steeper. In the middle the lake is squeezed between steep vertical rock walls 20$25 \mathrm{~m}$ high, and at its narrowest, the lake is only $15 \mathrm{~m}$ wide. At its northern end the lake widens into an almost circular basin that has a diameter of $120-140 \mathrm{~m}$ and is surrounded by steep rock walls 30-40 meters above the lake surface 

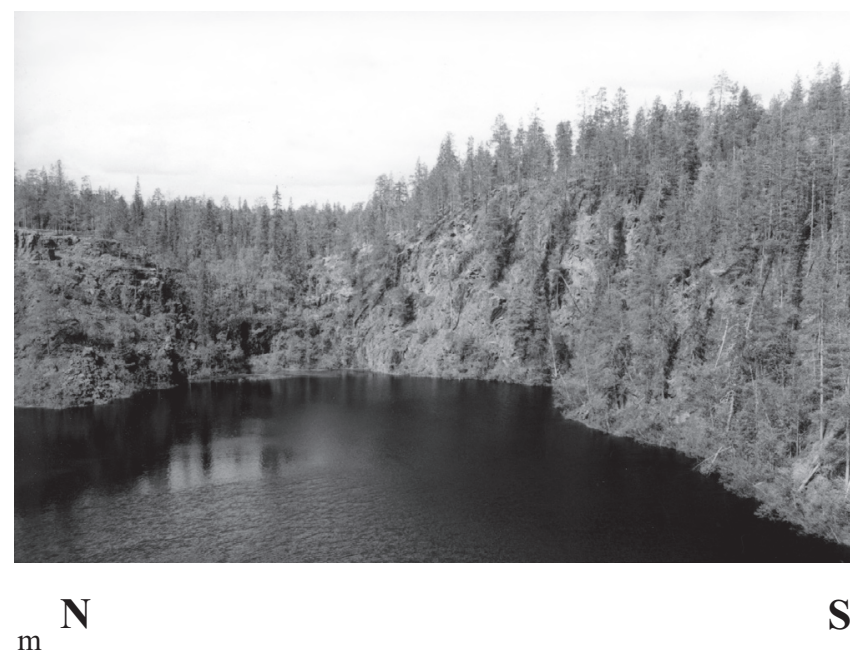

0

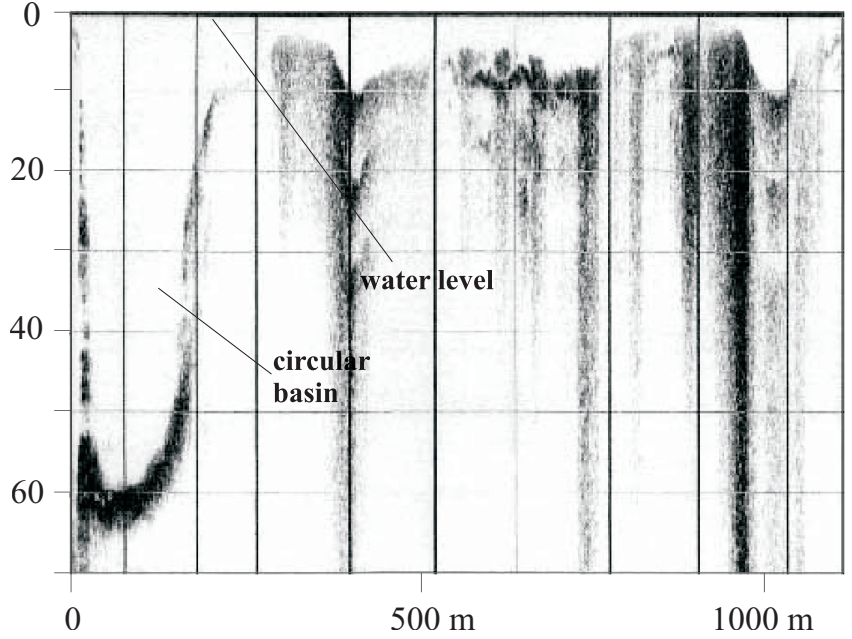

Fig. 3. At the northern end of the Pakasaivo canyon lake, the steep rock cliffs rise up to $40 \mathrm{~m}$ above the surface of the lake.
Fig. 4. Longitudinal profile obtained by echo sounding of the Pakasaivo canyon lake. The pothole-shaped basin at its left end is approximately $120-140 \mathrm{~m}$ wide and $60 \mathrm{~m}$ deep. The bottom consists of bedrock or boulders, while the bedrock in the central and southern part of the lake is covered by a mud deposit less than one meter thick.
(218 m above sea level) (Saarnisto, 1991). The rock walls are steplike. Weathering has formed hollows and caves within the steps that can be over two meters deep. Talus cones are found at the foot of the slopes (Fig. 3).

The depth of Pakasaivo was determined in the summer of 2000, using an echo sounder (Furuno FE-881 MK-II). A longitudinal profile of the lake from south to north revealed a few basin-like deeps, separated by rock ridges where the water depth is $8-10 \mathrm{~m}$ (Fig. 4). The bedrock or talus material on these rock ridges is covered by a thin layer of mud. At the northern end of the lake, the bottom drops precipitously, the depth being 60 meters (Fig. 4). The Pakasaivo canyon has $100 \mathrm{~m}$ of relief from the bot- tom of the lake to the top of the canyon wall, making it the second deepest lake in northern Finland (Karlsson, 1986). The echo-sounding profiles explain that the walls under water consist of rock (Fig. 4).

\section{Evidence for meltwater action around Pakasaivo}

The Pakajärvi esker crosses the Valkeajoki River valley extending northwest of the lake Pakajärvi and southwest towards the Keinokursu gorge. It forms part of an esker system that spans several hundred kilometers in length, beginning south of the village of Kihlanki and continuing northwestwards to Pakasaivo and then northwards to 
Muonio (Johansson et al., 1989). It follows the depressions and valleys in the direction of ice retreat, which is typical of the eskers in the area. As most esker systems, this one does not consist of a continuous esker ridge. Between the esker ridges and hills there are landforms created by meltwater erosion as well as zones with no signs of meltwater action (Johansson, 1995). Because these zones are short, the esker system can be traced in a NNW direction across the river Muonionjoki into northern Sweden (Nordkalott Project, 1987).

Depositional landforms related to the esker sequence are found in valleys and on gently sloping lower hillsides. The largest eskers in the field area are Karhuojankankaat, SW of the Karhulaki hill and the Pakajärvi esker, NE of it (Fig. 2) and are morphologically distinct. Karhuojankankaat is $15-20 \mathrm{~m}$ high with a flat and mostly even top. Higher up on the slope of Karhulaki the esker narrows into a low ridge. The walls of gravel pits in the esker show that it is composed of stratified sand and gravel with bedding that slopes gently towards the flanks. In contrast, the Pakajärvi esker is a steep-sided, sharp-crested ridge, about $1.5 \mathrm{~km}$ long, which begins on the NE slope of Karhulaki. From there it descends towards the NE and has an undulating longitudinal profile. The esker rises $30-40 \mathrm{~m}$ above the level of Pakajärvi, the adjacent lake. There are no cuts, but judging from the stony surface it consists of coarse-grained cobble gravel. NW of the esker ridge, on the southern shore of Lake Pakajärvi, there is a glaciofluvial formation that slopes gently towards the lake and covers an area of about $0.5 \mathrm{~km}^{2}$ (Fig. 2). Its surface morphology is variable, with hummocks of varying height and kettle holes between them.

The eskers are separated by deep gorges and channels incised into Karhulaki hill. The channels are either dry or contain small brooks. Their shapes resemble the erosional landforms created by rapidly flowing water. The largest of them is the Keinokursu canyon (Fig. 2), which connects with the esker ridges of Karhuojankankaat, and the Pakajärvi esker on either side of the hill. A deep cut into sediment and bedrock, Keinokursu is over four kilometers long, 50-150 m wide, and $30 \mathrm{~m}$ deep. The valley floor contains peaty layers, and the steep walls are 20-50 m high. On the SE slope of Karhulaki and on Hietaojankankaat there are canyons of similar shape, gently sinuous, 15$25 \mathrm{~m}$ deep and sloping into the Valkeajoki river valley. The morphology of Keinokursu gorge resembles the 'kursu' type canyons found in the area between Pajala and Karesuando in northern Sweden (Rudberg, 1949; Olvmo, 1989), some of which are considerably larger erosional landforms than the canyons described here.

\section{Deglaciation of the Pakasaivo area}

\section{I Subglacial environment}

The subglacial esker was formed in a meltwater tunnel at the base of the ice, in the marginal zone. This took place at the end of the last deglaciation. The formation of a subglacial meltwater stream required an impermeable bed as well as a long period when the ice sheet was in a dynamic state and the temperature at the base of the ice was stable, so that the flow of meltwater remained steady (Pair, 1997). This was possible only in a completely water-filled conduit where the meltwater stream, subjected to high hydrostatic pressure, was in balance with the pressure caused by the surrounding ice sheet. Because of the pressure, the meltwater tended to flow in the direction of the pressure gradients and towards the ice margin, where the pressure decreased as the ice became thinner (Shreve, 1972; Röthlisberger, 1972; Nye, 1973). According to Syverson et al. (1994), the conditions described above were possible when the thickness of the ice exceeded $100 \mathrm{~m}$. At that time the ice was still plastic and able to adjust, e.g., to the changes caused by the variable flow; such adjustment took place as widening or narrowing of the conduit and as changes in its shape (Lundqvist, 1979; Shreve, 1985).

The Keinokursu tunnel channel crosscuts bedrock ridges on the top of the Karhulaki hill. 

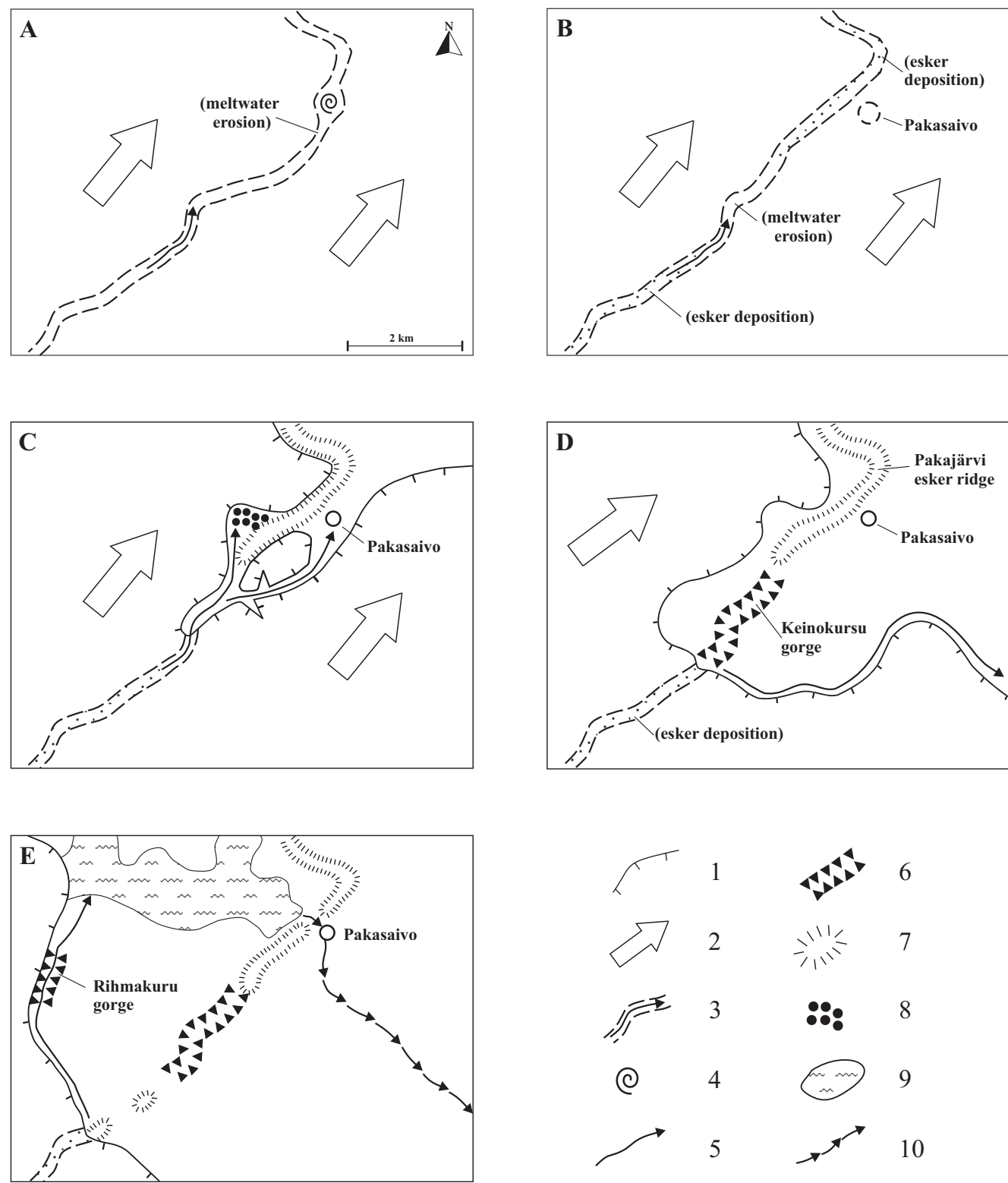

Fig. 5. Glaciohydrographic history of the Pakasaivo area. I = Ice margin, $2=$ Direction of ice flow, $3=$ Tunnel valley (subglacial meltwater system), $4=$ Whirl, $5=$ Marginal channel, $6=$ Gorge, $7=$ Esker, $8=$ Kettle holes, $9=$ Area covered by ice lake and $10=$ Spillway.

Since the Keinokursu tunnel channel clearly crosses a terrain obstacle, seems to connect the eskers formed subglacially at both ends, and since its longitudinal profile is convex, we can conclude that Keinokursu was formed as a result of erosion by pressurized meltwater flow- ing in a subglacial environment. Glaciofluvial erosion dominates across the upland. The glacial stream eroded its channel, passing through the overburden and the weathered rock down to the hard, crystalline bedrock and forming gorges and canyons cut deep into the rock (Fig. 
5a). As shown by the marginal channels branching out to the east, the meltwater flowed towards the NE, from the main channel towards the eastern slopes of the Karhulaki hill (Fig. 2). The channels were formed after the subglacial phase, as the meltwater that earlier was discharged from the mouth of the tunnel flowed along the ice margin. Presumably, the tunnel channel formation had a long life, as the channel cut into bedrock gave the meltwater stream better protection against the movements of the ice sheet than a channel eroded only into the ice (Nye, 1973).

As deglaciation progressed and the ice thinned out, the pressure in the meltwater tunnel fell and the process of erosion became a process of deposition (Fig. 5b). Sometimes this change also took place due to variations in landforms or flow conditions. However, the depositional landforms did not cover the erosional landforms everywhere. The Karhuojankankaat esker (Fig. 2) is located in a place where the meltwater flow in the subglacial conduit turned uphill. As the flow slowed down, the transporting capacity of the meltwater weakened and the abundant material transported by the stream accumulated on the floor of the conduit. Karhuojankankaat was deposited in the form of a flat esker, with a level top in places. It resembles the eskers deposited on uphill slopes in eastern Lapland (Johansson, 1995). According to Shreve (1985), studies of the Katahdin esker system in Maine showed that the flat tops of the eskers were formed as the meltwater conduit became low and flat subsequent to freezing of the walls of the conduit. This, in turn, was caused by the slowing of the stream, which is also reflected by the grain size of the deposits. Kujansuu (1967) found that the sediments in eskers that were deposited on the upstream side of the divide are better-sorted and finer-grained than the sediments in eskers on the downstream side.

The erosional and depositional landforms reflect the changes in glacier dynamics and the glaciofluvial environment during deglaciation. The bedrock of the present canyon is deeply fractured. The canyon was further deep- ened by the southwestern ice flow along it and by the glacial erosion that occurred on its floor. This, however, is insufficient to explain the formation of the canyon or its peculiar shape. Erosion by subglacial meltwater is the only way in which it could have been formed. Depending on the power of the stream and the extent of erosion it caused, the result can be various erosional landforms, e.g., polished rock surfaces, channels cut into the bedrock and its fractured parts, and gorges and canyons cut deep into the bedrock (Vivian, 1970). If the bedrock had already been fractured, the pressurized meltwater was able to erode gorges of considerable depth (Baker, 1987).

At the early stage of the last deglaciation, when the area was still covered by an ice sheet hundreds of meters thick, a powerful subglacial meltwater stream entered from Keinokursu into Pakasaivo and continued the work started by the glacier. As it flowed northeastwards, the ice had already eroded a fracture zone in the bedrock. Since its pressure was strong, the meltwater action was restricted to erosion only (Nye, 1973). The flow may have been accompanied by a powerful whirl, which concentrated the erosive force on a previously broken spot, grinding the hollow deeper and deeper (Fig. 5a). In order to form a basin the size of Pakasaivo, the meltwater erosion must have continued for a long time, and it must have started centuries before the ice sheet melted. However, observations made in the Alps indicate that considerable erosional landforms arose in a short time in consequence of an exceptionally powerful pressurized water whirl (Vivian, 1970). It is worth noting that rock faces visible above the water of Pakasaivo show no distinct surfaces polished by the meltwater stream, such as spindle flutes or sichelwannen, and no forms typical of potholes. The circular form of the lake seems to be the only distinct sign of some kind of subglacial waterwhirl (cf. Shaw 1996).

Channels that have been cut deeply into the overburden by meltwater, followed by esker deposition, can be found throughout northern Finland (Kujansuu \& Eriksson, 1995; 
Kujansuu \& Hyyppä 1995; Johansson \& Kujansuu, 1995). They illustrate that the subglacial erosional landforms are often related to the early stages of the meltwater system and are older than the depositional landforms. Before the Pakasjärvi esker was deposited north of Pakasaivo, the subglacial meltwater channel had shifted about $0.5-1 \mathrm{~km}$ towards the NW (Figs. 2 and 5b), which prevented the canyon from being filled with glaciofluvial material. Eskers did not start to form until the last stage of the deglaciation. They were deposited in the marginal zone, where the flow abated in consequence of the thinning of the ice, which also meant a drop in water pressure (Lundqvist, 1979; Ashley et al., 1991; Clayton et al., 1999). According to Banerjee \& McDonald (1975), the deposition of the esker on the tunnel floor was time-transgressive and started only a few kilometers before the edge of the retreating ice.

\subsection{Subaerial environment}

Lateral drainage channels are abundant in the Ylläs mountain area, $20 \mathrm{~km}$ east of the study area. Their orientation and slope suggest that the gradient of the melting ice margin was about $2 \mathrm{~m}$ per $100 \mathrm{~m}$ towards the NE (Abrahamsson, 1974; Kujansuu, 1967). Thus the ice surface had about the same gradient as the present NE slope of Karhulaki (Fig. 2). The ice sheet thinned at a rate of $2.2-3 \mathrm{~m}$ a year, and the ice margin retreated about $50 \mathrm{~m}$ annually (Kujansuu, 1967). The deposition of the Pakajärvi esker ridge ended with the formation of fractures and crevasses that extended through the whole thickness of the ice sheet. The fractures and crevasses gave the air access to the base of the ice sheet, causing the hydrostatic pressure of the meltwater stream to fall. According to Röthlishberger (1972), the ice sheet loses its plasticity and cannot maintain the pressure in a meltwater tunnel at its base when it is less than $50 \mathrm{~m}$ thick. After the ice had broken up, the subglacial meltwater stream flowing in Keinokursu became subaerial (Fig. 5c).
At the subaerial stage, for a short time Keinokursu became an open channel, along which the meltwater discharged from the tunnel flowed around the Pakajärvi esker ridge to the east towards Pakasaivo and to the north, towards the Pakajärvi lake. The kettles on the shore of the lake were formed as ice blocks dislodged from the edge of the meltwater channel, were transported with the stream and buried with the glaciofluvial material. The meltwater erosion still continued in the subaerial environment, but the Keinokursu channel had already been formed and its location been defined earlier, in the subglacial environment. The formation of kursu canyons that resemble Keinokursu in northern Sweden has been interpreted as completely subaerial. According to Rudberg (1949) and Olvmo (1989), canyons of such dimensions can be formed only by a combination of meltwater erosion in an open channel and weathering of the rock walls due to temperature variations. At Keinokursu, however, nothing suggests subaerial formation, as subglacial esker ridges form continuations of the gorge at both ends, and the longitudinal profile of the canyon is convex. The meltwater stream could have flowed uphill and over Karhulaki only in a pressurized environment at the base of the ice sheet.

\subsection{Submarginal environment and ice lake stage}

As the ice thinned out and the hydrostatic pressure decreased, the meltwater could no longer cross the Karhulaki hill from the SW towards the NE along Keinokursu. The slopes of Karhulaki clearly show how the meltwater emerging from the mouth of the subglacial tunnel turned eastward, flowing along the slopes of Karhulaki and forming a network of submarginal and sublateral meltwater channels (Figs. 2 and $5 \mathrm{~d}$ ). The meltwater flowed to the Valkeajoki river valley south of Pakasaivo. At the final stage, some meltwater also flowed north through the Rihmakursu canyon (Figs. 2 and 5e). 
Meltwater was dammed up in front of the retreating ice margin; the result was the formation of the Muonio Ice Lake. It covered three hundred square kilometers in the Muonionjoki river valley (Kujansuu, 1967; Johansson et al., 1989) (Fig. 1). In the region between the mountains Pallas-Ounastunturi and Ylläs, there are several gorges and channels, that acted as spillways. The spillways led eastward to the deglaciated Ounasjoki river valley (Fig. 1). Directly related to the Pakasaivo canyon is the spillway located about $10 \mathrm{~km}$ north of the study area, at Jokijärvi, that regulated the water level of the ice lake at about $243 \mathrm{~m}$. After the remnants of the ice sheet disappeared from the vicinity of Pakajärvi and Pakasaivo, a new spillway of the ice lake was formed at Pakasaivo. The water from the ice lake surged into the Pakasaivo canyon, continuing through it southward to the Valkeajoki valley (Figs. 2 and 5e). The surface of the ice lake sank to a level of $238 \mathrm{~m}$. After this discharge, the Muonio Ice Lake had its spillway through Pakasaivo for decades, until the margin of the ice sheet retreated from the Pakasaivo-Ylläs region, which caused the emptying of the ice-dammed lake.

The discharge of the ice lake and the subsequent spillway phase influenced the shape of $\mathrm{Pa}$ kasaivo and its deep, hollow basin. The water discharged from the ice lake surged forcefully across the rock threshold NW of Pakasaivo into the lake. In fact, the form of the steep northern shore of Pakasaivo resembles a cataract lip (Fig. 3). The deep hollow of the lake itself may be a plunge pool lake formed at the base of the cataract. Similar deep basins created by the discharge of ice dammed lakes are found, e.g., Dry Falls in the Channeled Scabland, in Washington state (Baker, 1978; 1987), where the meltwater excavated a deep canyon in broken rock. The water rushing into the hollow of Pakasaivo yielded vertical vortices that caused a turbulent plucking action. Consequently the rock debris was transported away from the deep part of the lake. Later, blocks and stones that had been weathered off the steep cliffs and loosened from the slopes rolled down, forming a talus cone on the shore.

\section{Conclusion}

In view of its location, the Pakasaivo canyon lake, with its deep circular basin at the northern end, is clearly related to the subglacial meltwater system that runs across the area, including esker ridges and the subglacial tunnel channel of Keinokursu. However, the study area contains no proof indicating that subglacial erosion alone could have created a hollow almost a hundred meters deep in the bedrock. The formation of Pakasaivo is obviously polygenetic.

The Pakasaivo lake is situated in a northsouth fracture zone in the bedrock, where the monzonite rock has a cubic jointing pattern and apparently was broken long before the glaciations. During the Late Weichselian glaciation phase, the northeastward-flowing ice sheet caused glacial erosion in the broken bedrock. The subglacial meltwater stream flowing through the canyon further eroded the bedrock, and at the northern end of the lake, where the lake is deepest, a powerful water whirl was probably generated, grinding the hollow deeper and deeper. The water whirl also contributed to the circular shape of the hollow. The route of the meltwater stream shifted more to the NW before the eskers were deposited. In consequence, the Pakasaivo canyon was covered with ice and thus was not filled with the glaciofluvial material transported by the meltwater. The water from the Muonio Ice Lake, which flowed southward towards the end of the deglaciation, added to the erosion accomplished by the subglacial meltwater. It also seems to have had an effect on the shape of the hollow and the steep cliff on its northern shore. Today they together resemble a dried-up cataract with a plunge pool formed at its base.

Abundant signs of meltwater systems older than the last glaciation have been found in Finnish Lapland. It has been proposed that the meltwater of some ice sheet at a point in time earlier than the last glaciation could have created the canyon, but no obvious signs of earlier meltwater action have been detected. The area has proof only of meltwater action related to the 
deglaciation phase of the last glaciation. It is thus concluded that Pakasaivo and the landforms created by meltwater in its surroundings were formed and attained their present appearance during the final stage of the last glaciation.

\section{Acknowledgements}

The study was carried out in connection with the basic mapping of Quaternary deposits in the area, performed by the Geological Survey of Finland (GTK). I express my gratitude to the Geological Survey and its staff for their help during the field investigations, and particularly to Mr. Hannu Hirvasniemi, Mr. Sep-

\section{References}

Abrahamsson, K., 1974. Äkäslompolo-områdets glacialmorfologi och deglaciation. Umeå Universitetet, geografiska rapporter. Rapport B1, 254 p.

Ashley, G.M., Boothroyd, J.C. \& Borns; H.W.Jr., 1991. Sedimentology of Late Pleistocene (Laurentide) deglacial-phase deposits, eastern Maine: An example of a temperate marine grounded ice-sheet margin. In: Anderson, J.B. \& Ashley, G.M. (eds.) Glacial marine sedimentation: Paleoclimatic significance. Geological Society of America Special Paper 261, 107-125.

Baker, V.R., 1978. Paleohydraulics and hydrodynamics of scabland floods. In: Baker, V.R. \& Nummedal, D. (eds.) The Channeled Scabland: A guide to the Geomorphology of the Columbia Basin, Washington. Planetary Geology Program, National Aeronautics and Space Administration, 59-79.

Baker, V.R., 1987. Dry falls of the Channeled Scabland, Washington. Geological Society of America Centennial Field Guide-Cordillieran Section, 369-372.

Banerjee, I. \& McDonald, B.C., 1975. Nature of esker sedimentation. In: Jopling, A. V. \& McDonald B. C. (eds.) Glaciofluvial and glaciolacustrine sedimentation. Society of Economic Paleontologists and Mineralogists Special Publication 23, 132-154.

Brennand, T.A., 1994. Macroforms, large bedforms and rhythmic sedimentary sequences in subglacial eskers, south-central Ontario: implications for esker genesis and meltwater regime. Sedimentary Geology 91, 9-55.

Brennand, T.A., 2000. Deglacial meltwater drainage and glaciodynamics: inferences from Laurentide eskers, Canada. Geomorphology 32, 263-293.

Clark, P.U. \& Walder, J.S., 1994. Subglacial drainage, eskers, and deforming beds beneath the Laurentide and Eurasian ice sheets. Geological Society of America Bulletin 106, 304-314.

Clayton, L., Attig, J.W. \& Mickelson, D.M., 1999. Tunnel channels formed in Wisconsin during the last glaciation: In: Mickelson, D.M. \& Attig, J.W. (eds.) Glacial processes Past and Present. Geological Society of America Special Paper 337, 69-82. po Putkinen and Mr. Jorma Valkama for their assistance with the echo sounding. Mrs. Carola Eklundh translated the manuscript into English and Mrs. Viena Arvola drafted the maps; I extend my sincere thanks to them. I am especially grateful to Professor Bertil Ringberg (Stockholm University), Professor Timothy G. Fisher (Indiana University Northwest) and to the journal referees, Professor Matti Eronen (University of Helsinki), Dr. Kurt H. Kjaer (Lund University) and editor Dr. Petri Peltonen for their constructive comments on the manuscript and for their valuable advice, which I highly appreciate.

Editorial handling: Y. Kähkönen and P. Peltonen

Hirvas, H., 1991. Pleistocene stratigraphy of Finnish Lapland. Geological Survey of Finland, Bulletin 354 $123 \mathrm{p}$.

Holtedahl, H., 1967. Notes on the formation of fjords and fjord valleys. Geografiska Annaler 49 A, 188203.

Johansson, P., 1995. The deglaciation in the eastern part of the Weichselian ice divide in Finnish Lapland. Geological Survey of Finland, Bulletin 383, 72 p.

Johansson, P., Maunu, M., Mäkinen, K., Sutinen, R. \& Väisänen, U., 1989. Muonio. The Map of Quaternary deposits and its Explanation. Sheet 2723 2. Geological Survey of Finland, Rovaniemi.

Johansson, P. \& Kujansuu, R., 1995. Observation on three subglacial drainage systems of different age in Savukoski, eastern Finnish Lapland. In: Autio, S. (ed.) Geological Survey of Finland, Current Research 1993-1994, Geological Survey of Finland, Special Paper 20, 83-93.

Karlsson, K.-P. (ed.), 1986. Atlas of Finland, folio 132, Water. National Board of Survey and Geographical Society of Finland, Helsinki, $31 \mathrm{p}$.

Kujansuu, R., 1967. On the deglaciation of western Finnish Lapland. Bulletin de la Commission géologique de Finlande 232, 96 p.

Kujansuu, R. \& Eriksson, B., 1995. Pre-Late Weichselian subglacial glaciofluvial erosion and accumulation at Vuotso, Finnish Lapland. In: Autio, S. (ed.) Geological Survey of Finland, Current Research 19931994, Geological Survey of Finland, Special Paper 20, 75-82.

Kujansuu, R. \& Hyyppä, J., 1995. Vuotson karttaalueen maaperä. Summary: Quaternary deposits in the Vuotso map sheet area. Geological map of Finland 1:100 000. Explanation to the maps of Quaternary deposits, sheet 3742, Vuotso. Geological Survey of Finland, 107 p.

Lehtonen, M., 1981. Kihlanki. Geological Map of Finland 1:100 000, Pre-Quaternary Rocks, sheet 2714. Geological Survey of Finland. 
Lundqvist, J., 1969. Beskrivning till jordartskarta över Jämtlands län. Summary: Description to the map of the Quaternary deposits of the County of Jämtland, Central Sweden. Sveriges Geologiska Undersökning Ca 45, 418 p.

Lundqvist, J., 1979. Morphogenetic classification of glaciofluvial deposits. Sveriges Geologiska Undersökning C 767, $71 \mathrm{p}$.

Mannerfelt, C.M:son., 1945. Några glacialmorfologiska formelement och deras vittnesbörd om inlandisens avsmältningsmekanik i svensk och norsk fjällterräng. Summary: Some glaciomorphological forms and their evidence as to the downwasting of the inland ice in Swedish and Norwegian mountain terrain. Geografiska Annaler 27, $239 \mathrm{p}$.

Mikkola, E., 1932. On the physiography and the late-glacial deposits in northern Lapland. Bulletin de la Commission géologique de Finlande 96, $88 \mathrm{p}$.

Nordkalott Project, 1987. Map of Quaternary geology; sheet 1: Quaternary deposits, northern Fennoscandia 1:1 000 000. Geological Surveys of Finland, Norway and Sweden.

Nye, J.F., 1973. Water at the bed of a glacier. Symposium on the Hydrology of Glaciers, Cambridge, 9-13 September 1969. Publication de l'Assosiation Internationale d'Hydrologie Scientifique 95, 189-194.

Olvmo, M., 1989. Meltwater canyons in Sweden. A study of canyons of the "kursu", "skura" and "grav"-type. University of Göteborg, Department of Physical Geography, Rapport 27, 126 p.

Pair, D.L., 1997. Thin film, channelized drainage, or sheetfloods benath a portion of the Laurentide Ice Sheet: an examination of glacial erosion forms, northern New York State, USA. Sedimentary Geology 111 , 199-215.

Penttilä, S., 1963. The deglaciation of the Laanila area, Finnish Lapland. Bulletin de la Commission géologique de Finlande 203, 71 p.

Röthlisberger, H., 1972. Water pressure in intra- and supraglacial channels. Journal of Glaciology 11, 177203.
Rudberg, S., 1949. Kursudalar i Norrbotten, en preliminär översikt. Meddelande Uppsala Universitetets Geografiska Institutionen A 64, 442-495.

Saarnisto, M., 1991. Tornionlaakson geologiset kehitysvaiheet. In: Hederyd, O., Alamäki, Y. \& Kenttä, M. (toim.) Tornionlaakson historia I. Jääkaudelta 1600-luvulle. Malungs Boktryckeri, Mahlung, Sweden, 11-44.

Saarnisto, M., 2000. The last glacial maximum and the deglaciation of the Scandinavian Ice Sheet. In: Sandgren, P. (ed.) Environmental changes in Fennoscandia during the Late Quaternary. LUNDQUA Report 37, 26-31.

Shaw, J., 1996. A meltwater model for Laurentide subglacial landscapes. In: McCann, S.B. \& Ford, D.C. (eds.) Geomorphology Sans Frontiéres. Wiley, Chichester, New York, 181-236.

Shreve, R., 1972. Movement of water in glaciers. Journal of Glaciology 11, 205-214.

Shreve, R., 1985. Esker characteristics in terms of glacier physics, Katahdin esker system, Maine. Geological Society of America Bulletin 96, 639-646.

Sissons, J.B., 1961. Some aspects of glacial drainage channels in Britain. Part II. Scottish Geographical Magazine $77,15-36$.

Sugden, D.E. \& John, B.S., 1976. Glaciers and Landscape. Edward Arnold, London. 376 p.

Syverson, K.M., Gaffield, S.J. \& Michelson, D.M., 1994. Comparison of esker morphology and sedimentology with former ice-surface topography, Burroughs Glacier, Alaska. Geological Society of America Bulletin 106, 1130-1142.

Tanner, V., 1915. Studier öfver kvartärsystemet i Fennoskandias nordliga delar III. (Résumé en français: Etudes sur le système quaternaire dans les parties septentrionales de la Fennoscandie). Bulletin de la Commission géologique de Finlande 38, 815 p.

Virkkala, K., 1955. On glaciofluvial erosion and accumulation in the Tankavaara area, Finnish Lapland. Acta Geographica 14, 393-412.

Vivian, R., 1970. Hydrologie et érosion sous-glaciaires. Revue de la Géographie Alpine 58, 241-264. 